tions, now also form two series: the Science Parts being published twice a year, in December and April, and the Polite Literature and Antiquary Part once a year, in December. Quite recently the Academy have determined to publish another series of quarto Transactions under the title of "The Cunningham Memoirs," part I of the first volume of which, containing a memoir by Dr. John Casey, F.R.S., on Cubic Transformations, has just appeared.

The publications of the Royal Dublin Society are of the same type as those of the Irish Academy, except that they are exclusively confined to science. Of their new series of Transactions, parts I to 13 of volume I have been published, and for convenience of publication the first two parts of volume 2, containing "Observations of Nebulæ and Star Clusters, 1848-1878," by the Earl of Rosse, have also appeared. The first two volumes of these Proceedings have been published, and a part makes its appearance pretty regularly every third month. Following the example of the Academy, the memoirs forming the Transactions are published separately.

It would thus appear that not only is there evidence of scientific life among the societies of Dublin, but that there is also an abundant opportunity for the publication of any really valuable scientific information, and so far at least as the publications of the Irish Academy are concerned they fall in no respect as regards type, paper, or illustrations, behind the best of our London societies.

\section{JOHN DUNCAN}

$A$ LONG with a cheque for $5 l$. to John Duncan, whose story was told by Mr. W. Jolly in NATURE of January 20 , we have received the following note from Mr. W. Westgarth :-

January $27, \mathbf{1} 88 \mathbf{1}$

DEAR SIR, - On reading the account of John Duncan in you last week's issue, it occurred to me that surely your readers would respond to your invitation to get up a small fund, say of $100 \%$ to $200 \%$., for the brave old man who has so long and perseveringly fought, and against all "odds," for the cause of science and mind. I enclose $5 l$. towards the object. Should you see objections to opening a list in NATURE, please send on my small dole to Mr. Jolly as he directs.

W. WESTGARTH

We have the greatest pleasure in acting upon $\mathrm{Mr}$. Westgarth's hint, and we trust that many of our readers will be prompt to follow his good example. Subscriptions addressed to the Editor of NATURE, 30, Bedford Street, Covent Garden, W.C., will be duly forwarded. We have already received the following :-

$\begin{array}{lllllllllll}\text { W. Westgarth } & \ldots & \ldots & \ldots & \ldots & \ldots & 5 & 0 & 0 \\ \text { Publishers of NatURE } & \ldots & \ldots & \ldots & \ldots & 5 & 5 & 0 \\ \text { F.R.S. } & \ldots & \ldots & \ldots & \ldots & \ldots & \ldots & \ldots & \text { o } & \text { I0 } & 0 \\ \text { Mrs. Forster } & \ldots & \ldots & \ldots & \ldots & \ldots & \ldots & \text { I } & 0 & 0\end{array}$

\section{CASSELL'S NATURAL HISTOR $Y^{1}$}

$\mathrm{T}^{\mathrm{s}}$ $\mathrm{E}$ third volume of this useful cyclopædia of zoology consists of the concluding portion of the Birds by R. Bowdler Sharpe, and of the Reptiles and Amphibia by the Editor. On glancing over the well-printed and beautifully-illustrated pages, a few facts have struck us, to which, for the benefit of the series, we would call the editor's attention. In the opening sentence of Chapter I. of this volume we are referred to "the preceding chapters" for an account of the Picarian birds. The context proves it should be to the preceding volume. This, which might mislead the reader, is evidently the result of the publication of the work in parts, and could be easily avoided.

All through Mr. Sharpe's portion of the work, when the scientific names of birds are referred to they are x "Cassell's Natural History." Edited by Prof. P. Martin Duncan, M.B., F.R.S. Vol. IYI. (London, Paris, and New York : Cassell, Petter, Galpin, and Co., 1880.) quoted generally within brackets in the same line as the popular name; while in the editor's special portion no such useful uniformity is attended to. Sometimes, as on p. 245 , the eye has to wander from the text to foot-notes at the bottom of the page; sometimes, as at p. 248 , the name is quoted after Mr. Sharpe's fashion (for a mixture of both styles see p. 362). "The use of the word "kind," when the editor refers to "species", is in our judgment, though perhaps sanctioned by its use in the English translation of the Bible, not happy. Thus we read that, while genera among the reptiles are abundant, "kinds" are numerous. The "kinds" of some families swim freely; some "kinds" have a skin; by the way, what kind of a reptile be it that has no skin? In other cases the word "member" instead of species is used. Is it not a mistake to say that in many Chelonians "the wellknown 'tortoise-shell' covers over all the hind parts." Surely in Caretta squamosa the tortoise-shell plates cover over most of the carapace. While the families of the Chelonian order are given, we find, when we come to the Lacertine order, no intelligible mention of the families of the split-tongued lizards. In referring to the important paper on Archæopteryx by the Professor of Geneva, the editor ought to have seen that the name of Carl Vogt was correctly spelled. The divisions of the Snakes is such as must necessarily confuse any student. The suborder Thanatophidia is made to include two sub-orders in the text, when in the table of classification one of these sub-orders, Solenoglypha, is called a family. The groove-fanged Opisthoglypha are included with the Aglyphodontia with solid teeth. In a work of this nature nothing is, we take it, of more importance than that there should be some well-defined system of classification, not necessarily to be treated of in full detail, but as far as is possible to be rigidly adhered to. That this is possible, a glance over the sections of this and the previous volume treating of Birds will abundantly demonstrate; and that this is practicable, even with an extreme compression of space, is also to be proved by an appeal to the way in which the eighth order of Birds is managed, where, though only three pages were allowed to this most interesting and important of orders, yet we are even in these few lines enabled to get an idea of the orderly sequence of its families. This work is in many ways so excellent, that we venture on these criticisms with the object of trying to keep it up to a fairly good standard, and of making it useful in some measure as a work of reference.

As specimens of the excellent illustrations in this volume we have, through the courtesy of the publishers, the opportunity of presenting to our readers the two following. The Common Quail (Coturnix dactylisonans) visits Europe in the summer, when prodigious numbers are trapped and sold for purposes of food. Waterton mentions that 17,000 specimens were brought to Rome in one day. They are to be found in large quantities on the coasts of the Mediterranean, and so abundant are they in the beautiful Island of Capri, that it is said that it was from this source that the bishops in the olden times derived a large part of their wealth. The Quail is most rapid in its flight, and performs long and fatiguing journeys. Sunset is its time for active exertion ; during the day it remains quite quiet, reserving its energies for the evening, when it goes off in quest of food.

Their favourite nourishment is insects, but at times they feed on grain and seeds; small stones are also swallowed to facilitate digestion. The habits of the quail are most unamiable and unsocial, and generally, when they meet with one of their own species, they display a very pugnacious disposition. The female has a much better nature; she is a most excellent mother, even protecting young birds who have been deprived of their parents' care. She builds her nest of small portions of plants, and lays eight to fourteen eggs; these are pear- 
shaped in form, of a light-brown colour, marked with a darker shade; the young seem full-grown when only six months old, and are ready to join their parents in their long autumn journey, which may extend as far as the Cape of Good Hope, where they are known to arrive in large numbers. The quail, unlike the partridge, also figured in our illustration, has several wives, and displays great spirit in keeping rivals at a distance; while the mother is attending to the care of her young ones, the cock bird, too, often amuses himself in the vicinity with his companions.

Our second ustration is taken from the bigher of the two classes of the Ichthyopsida, known as the Amphibia; these skull-bearing animals have no amnion and but a rudimentary allantois, and they breathe by gills at some period of their life. In this volume they are placed as an independent class alongside of the Sauropsidian reptiles. Among the permanently tailed Amphibians (Urodela) the sub-order containing those species with gills that fall off (Caducibranchiata) contains the interesting species known as Salamanders. It is of one of these of which we give the accompanying figure, not only as a fair specimen of those in the volume we are reviewing, but also in the hope of awakening some interest in a rather uncommon

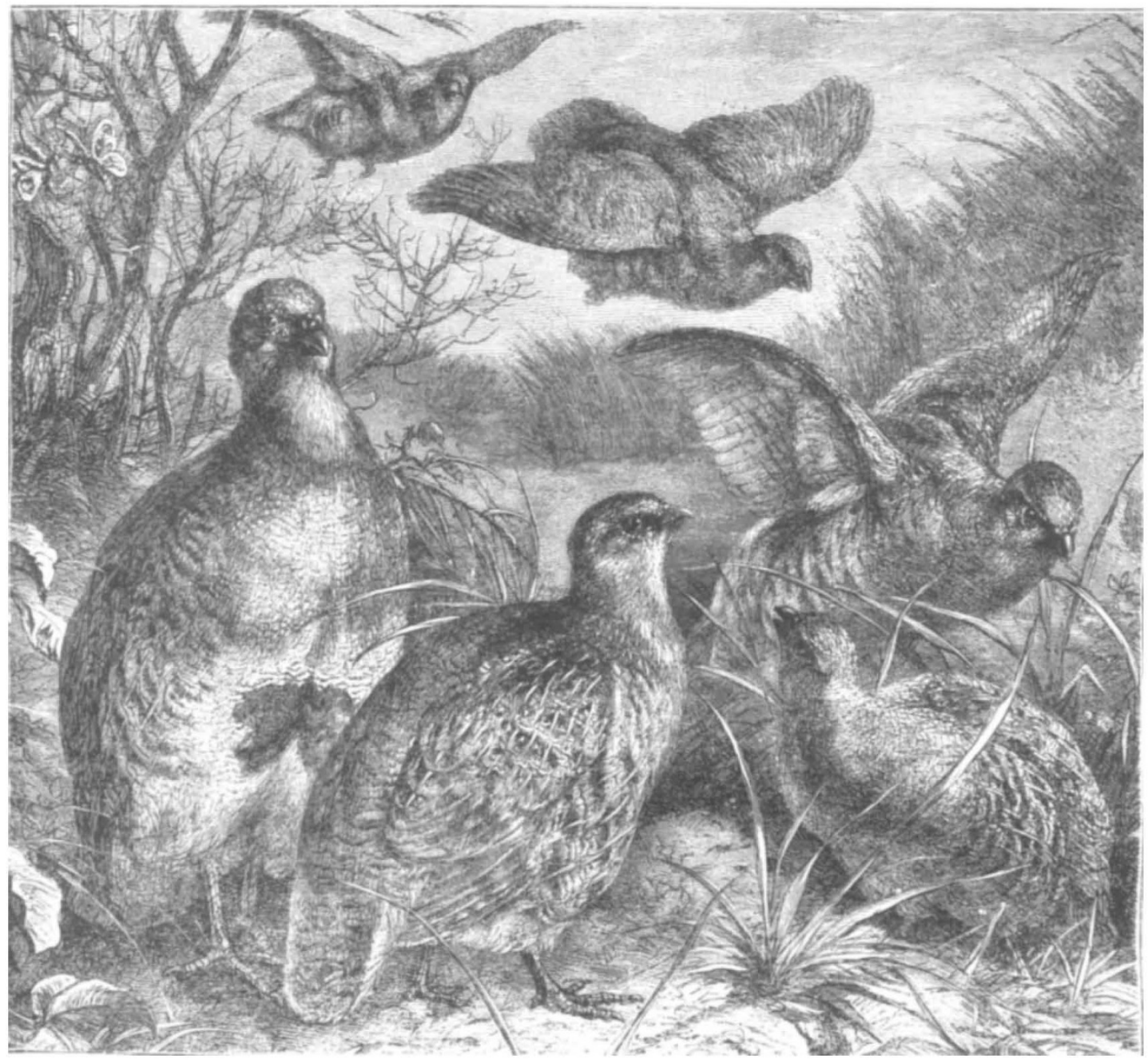

Fig. x. The Partridge and the Commun Quail.

Amphibian. "The next genus [to Salamandra], Pleurodeles, has short ribs, which give the appearance as if they penetrated the flanks, but their ends come against the tissue under the skin and produce horny projections thereon. The tail is long and compressed, and the small tongue is adherent only in front, and there are two series of palatine teeth in longitudinal series. The Spanish kind $(P$. Waltlii) has an ashy grey body, very prettily marked with long transverse stripes and dots. It is like a heavy lizard." Lord Clermont, in his useful work on the Reptiles of Europe, describes the tongue as small, warty, free behind and on the sides, adhering in front; he also describes the ribs as piercing the skin, and they are also said by some to be capped by horny tubercles; but this is denied by Leydig. Prof. St. George Mivart tells us that this species differs from all the other Urodela in the length and strength of its ribs, the longer ones considerably exceeding the length of two of the longest vertebræ of the body. M. Waltl first discovered it at Chiclana in Spain; Schinz states that it is very common in Andalusia in tanks and cisterns of water; Wallace gives its distribution as Spain, Portugal, and Morocco. Lord Clermont hints that the Bradybates zentricosus of Tschudi is probably the ycung of this species.

Now when Lord Clermont wrote his book there was not much more known about this interesting little animal, 
but some sixteen months ago Dr. F. Leydig of Bonn published an excellent account of it in Wiegmann's Archiv, in which he gives a short account of Dr. Joseph Waltl, who first discovered Pleurodeles, and of the gallant Dr. Michahelles, who called it after his friend, its discoverer (1830). Among the specimens sent to Bonn, one was living, and in it could be easily seen the tips of some of the ribs sticking through the skin; and that "this penetration" of the skin of the sides was not in the first instance caused by or through the transport, the accompanying note from the kind sender proved. "You will remark that in the Pleurodeles the ribs pierce the integuments, and that if this be an accident, it is in some sort a physiological one." The habits of the Pleurodeles seem to be more or less like that of our native Tritons. During the procreative season they remain upright in the water; later they leave it and hide themselves in damp places under stones. Like the Water Newts, they possess a sort of cry; when frightened, as on being suddenly seized, they emif a low, short, almost squeaking sound, generally repeated several times. This seemed to come not so much from the throat as to be caused by a rapid expulsion of air through the openings of the nose-in fact, to be a sort of snort.

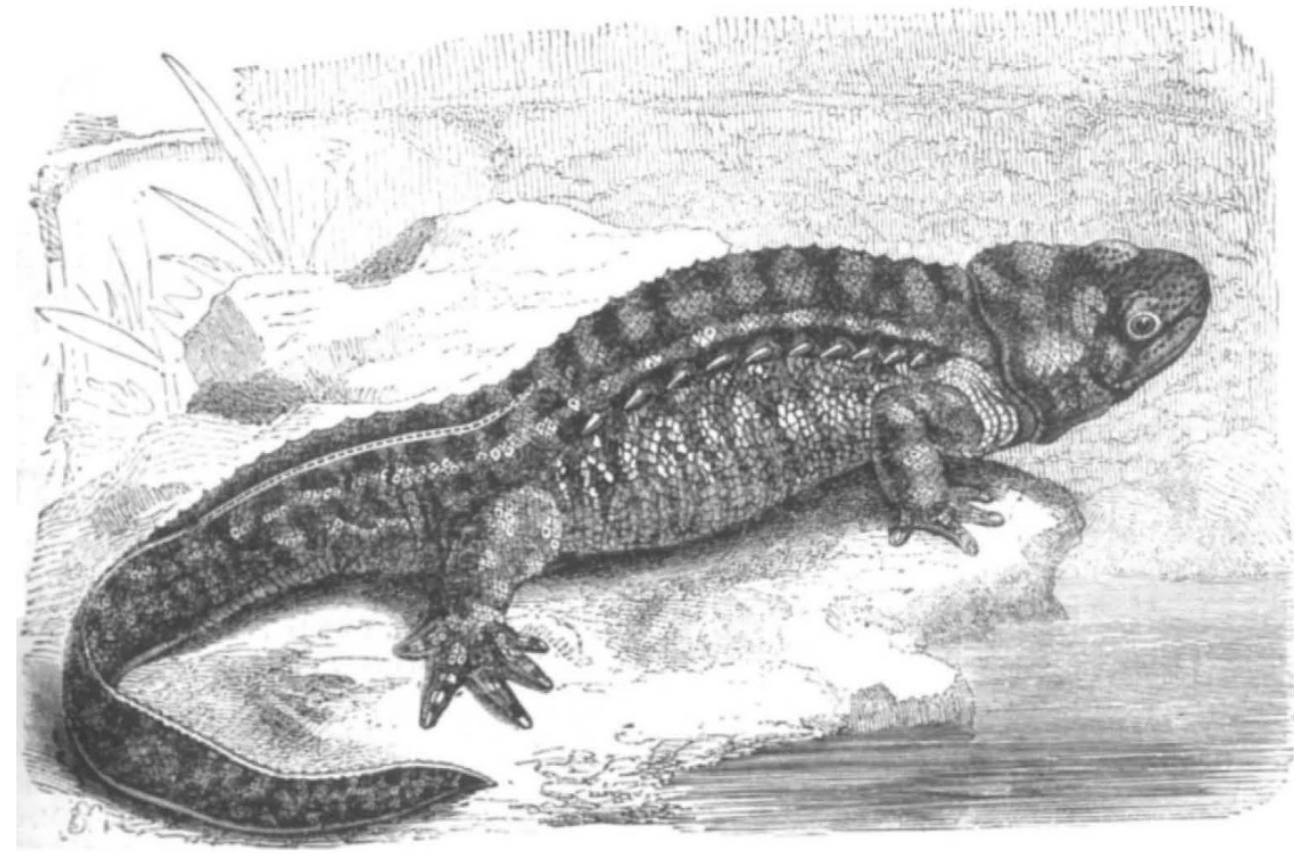

FIG. 2,-Pleurodeles tiraltiti

It had a tendency to crawl vigorously backward when uneasy, by prising the ends of the ribs against the skin : this snake-like progression no doubt causing the skin openings. Prof. Leydig's specimen lived on slugs of small size, which it took eagerly as well as worms, indeed preferring these latter. The skin surface was rather dry than claminy. The colour changes through the chromatophores were clearly to be noticed; during cold weather it was of a tolerably uniform dark, when warmer the colour became lighter, numerous dark spots standing out from a light gray ground colour. On very warm days it would lie for hours motionless on the surface of the water.

\section{NOTES}

THE $A k h b a r$ published a programme of the excursions which have been arranged for the next session of the French Association at Algiers on April I4. The excursions are very numerous, and are classified according to the length of time required for their completion. One of the most attractive in the vicinity of Algiers is the tomb of the Kings of Mauritania ; Laghouat and the desert is one of the most protracted, and requires eight days for its completion. The travellers will enjoy unexampled facilities for visiting the country. The seat of the French Association is 76 , rue de Rennes, Paris. Applications are to be made to M. Gariel, Professor of Physics to the Ecole de Medicine, permanent secretary. A reduction of 50 per cent. has been granted by the railway companies; the arrangements made for the sea passage will be published in proper time. An influential
It would almost seem worth one's while to pay a visit to those Andalusian tanks, and by their semi-limpid sides and under the shelter of their surrounding fig and olivetrees work out the complete history of this interesting little form.

These woodcuts will show that in point of illustration this volume keeps up with both its predecessors in effect; while we have gently hinted at a few blemishes, the work deserves a very considerable mead of praise, and we heartily recommend it as an excellent volume to be placet in the hands of all interested in the animal kingdom. local committee has been established in Algiers. M. Chauveau, Professor to the Veterinary School of Lyons, has been appointed president of the session; the vice-president is M. Janssen.

Mineralogical science has suffered a great loss by the early death, on Jantary 27, of Prof. Dr. Emanuel Boricky, who was well known by his microscopical researches in petrography. Boricky was born at Milín, near Príbram (Bohemia) in the year I840, and he had therefore just completed his fortieth year. In I 865 he became an assistant of the mineralogical section of the Bohemian Museum, and in 1866 he was named Assistant Professor of Mineralogy at the University of Prague. Having attained the degree of a Doctor of Philosophy, he became a teacher of mineralogy at one of the colleges of Prague in $\mathbf{1 8 6 8 ,}$ and in 1869 he was promoted to the post of a custos of the mineralogical collections at the museum. Since $187 \mathrm{I}$ he ha 